\title{
2 Performative, imaginary and symbolic power
}

\author{
How economic expert discourses \\ influence society
}

Jens Maesse

\section{Introduction}

Economic knowledge, ideas and concepts have a huge influence on society. The impact of economists extends across many institutions, realms and areas, such as banks and businesses, politics and administration, and it reaches (mediated by media and guidebooks) into people's daily lifestyles. However, to understand how the dissemination of expertise from science to society works is one of the main tasks of the social studies of economics. Whereas action-oriented approaches in the tradition of Max Weber highlight processes of persuasion, actors' interests and consensus among groups, as well as norms and values as devices for the transmission of economic expertise into society, structurally oriented approaches in the tradition of Marx and Bourdieu put their analytical focus on power, especially as it is represented by hierarchies, class structures, elite positions and other material constraints.

However, in order to understand the practical logic of power in economic expert discourses, a theory is needed that brings together the cultural as well as the structural dimension in these processes. Approaches in the vein of Michel Foucault and so-called performativity studies (inspired by the work of Callon, MacKenzie and others) took this challenge as a starting point for analysing how cultural and structural dynamics interact. Taking the Marxian and Bourdieusian traditions as a starting point and combining these with a Foucauldian approach, this chapter will ask how processes of discursive power can be analysed in economic expert communications as a way to overcome the culture/structure opposition. To this end, discursive power will be subdivided into performative, imaginary and symbolic power. In particular, I will show how and why performative, imaginary and symbolic power make visible different aspects of economic expert discourses. They are the key elements for analysing and understanding the different forms of an economic expert's impact on society.

The contribution is structured as follows. The first section (section 2) explains the idea of discursive power in the context of social studies of economics. Section 3 offers a definition of performative, imaginary and symbolic power in light of a Foucauldian conceptual framework. Section 4 takes examples from the Brexit discourse in order to illustrate each form of power. In addition, it 
will be indicated how these different forms might interact. The general aim of this chapter is not only to sketch out how discursive power operates in the case of economic expert discourses, but also to present a methodological framework that can be used in further analyses to study the impact of economic expertise.

\section{Forms of power in social studies of economics}

The influence of economic expert knowledge is analysed at different levels of society. According to Hall, economic ideas become powerful when they are promoted by professional economists, adopted and implemented by certain actors within the administration, or find support among a majority of politicians and civil society (Hall, 1989). Hirschman and Popp Berman identify three different channels of influence, from the economics profession to state and politics: professional authority, the institutional position of economists in policymaking and the general cognitive infrastructure of polity (Hirschman \& Popp Berman, 2014).

A deeper look at these three channels reveals that the first and third channels seem to be interlinked, because the authority of economists presupposes a certain cognitive infrastructure within society, politics and administration; and a preference for economics within the latter field will increase the probability of recruiting economic expertise as problem-solving knowledge. But, a distance between the economics profession and the state and society should be maintained. Otherwise, economists would directly rule society and the political economy. Against this backdrop, an open question in social studies of economics is how economic expertise is "transferred" through these channels.

One possible answer to grasp how the gap between economics knowledge and governance institutions can be bridged is "power". Many analyses, especially in the varieties of capitalism tradition, draw on Max Weber's theory of power and authority (Weber, 1972). Here, power (as authority) is analysed on the level of the formation of political values and norms through the construction of consent among actors. Accordingly, actors believe in the solution of social and political problems by applying certain economic concepts. The cultural sphere is of central importance here, because the influence of economic knowledge operates on the level of actors' opinions and perceptions. In contrast, Marxian and Bourdieusian approaches highlight the role of material power relations, hierarchies, political struggle and ideologies (Bourdieu, 1989). Here, power is understood as a means to move people's minds in a certain direction through symbolic coercion. In social studies of economics, many studies have analysed the impact of economics at the level of symbolic capital (Dezalay \& Garth, 2009; Lebaron, 2008; Rossier, Bühlmann, \& Mach, 2017; Schmidt-Wellenburg, 2017a). Symbolic capital does not operate on the level of actors' consciousness. Rather, it exercises different forms of coercion in the formation of governance institutions, policy programmes and worldviews, and it defines certain styles of thinking among ruling elites. Here, academic, administrative and political hierarchies and the role of certain elite actors within the 
field of economic power relations are much more influential when it comes to explaining why certain economic ideas take hold and others do not (Fitzgerald \& O’Rourke, 2015; Maesse, 2015; Pühringer \& Hirte, 2015).

Next to action-oriented (Weber) and structural (Marx/Bourdieu) theories, performativity theory has become established as a third type of approach to analyse the influence and power of economic expert knowledge (Callon, 2007). The original idea was to study economics as a meaning-making machine that does not analyse markets but reconstructs the economy according to a neoclassical worldview (MacKenzie \& Millo, 2003). Initially, this approach was criticised for promoting naïe neoliberal worldviews and ignoring economic realities (Mirowski \& Nik-Khah, 2008). Today, performativity studies no longer believe that economic theory is transformed into economic reality on a one-toone basis. Rather, processes of performation are analysed as a complex process of adoption, translation, implementation and critique, taking place between economic science and society, politics and the political economy. Thus, when economic concepts are used to solve political and economic problems, the concepts will be transformed and translated into different contexts (Boldyrev \& Svetlova, 2016). Performativity approaches have a deep relationship with the discursive character of the political economy (Maesse, 2018a).

Whereas action-oriented theories overestimate the interpretative capacity and cognitive sovereignty of actors in the course of the adoption of economic concepts, structural theories underestimate the interpretative and translational dynamics that are at work when economic ideas influence society. Furthermore, Weberian approaches reduce structural constraints, hierarchies and domination to merely institutional obstacles that can easily be overcome. They have a structural deficit. Marxian and Bourdieusian approaches pay too much attention to the rigidity of the structural level when analysing the influence of economic ideas. They very often have a translational deficit. Finally, performativity approaches can take into consideration the complex translational and discursive dynamics taking place between different social fields (such as science, politics, the economy and so forth). But they have a conceptual deficit since notions such as "power", "legitimacy" and "authority" are used very randomly and unsystematically.

An appropriate theory of power that is able to understand how economic expert knowledge influences society should keep the advantages of the aforementioned theories in mind but simultaneously find a solution for the disadvantages. It should meet the following criteria: first, it must take into account the structural constraints of heterogeneous social fields; second, it must be able to account for the translational and discursive logics that take place between various fields; third, it will analyse the diverse forms of use and adoption of economic concepts in non-academic and non-scientific contexts. Drawing on ideas inspired by the Foucauldian concept of dispositif (Foucault, 1980), the following chapter will outline a discourse-theoretical approach that is able to grasp processes of power in both its productive and coercive dimensions (Hamann, Maesse, Scholz, \& Angermuller, 2019). According to such a 
dispositif analytical understanding, power is always analysed according to its heterogeneous, transversal and heteroglossical character (Maesse, 2018b). The following chapter will explain in detail the scope and limitations of such a dispositif analytical approach for analysing economic expert discourses by sketching out three forms of discursive power.

\section{Three forms of discursive power: performative, imaginary and symbolic power}

Foucault's theory of power (Foucault, 2008) made important contributions to understanding what is going on in the formation of social and discursive relations based on structural constraints. Whereas Max Weber's sociology introduced the category of meaningful social action in order to analyse individuals' intentions and goals as forms of authority and legitimacy in contrast to Marxian and other structural approaches, Foucault's theory is still part of the structural camp in the social sciences. But in contrast to classical structuralism, Foucault's theory of power highlighted two important aspects of structural power dynamics: first, the fissures and fractures within structures that open up structured terrains for discursive conflicts over meaning; and second, the productive character of power which informs our view of social reality vis-à-vis oppressive as well as formative rules. Especially, the notion of governmentality has shown that exercising power is a decentralised phenomenon that cannot be reduced to one single mind (Weber's intention) and singular actors (Bourdieu's ruling classes). Rather, the discursive aspect of power always points to diverse modalities in the formation of power relations. It highlights the productive character of power and the biopolitical dimension of it, by showing how power strategies make things possible.

How can we grasp this often abstract and opaque poststructuralist theory with clear analytical units? I propose three different analytical categories that can help to understand how economic expert discourses influence societies as power devices: performative power, imaginary power and symbolic power.

Performative power can be defined as the possibility of economic expert discourses to create institutional infrastructures. Institutions will be understood, in a very broad sense, as often legally codified, but always socially fixed, fields of social action. These fields are hierarchically organised, as Bourdieu would claim, but they are at the same time open to other fields and in constant exchange with them. Networks and institutions usually fix these fields of economic expert action (Pühringer \& Hirte, 2015; Rossier \& Bühlmann, 2018). There is no single field logic, but each empirical field can be fixed in different ways. Despite this heterogeneity, fields are always the sedimented background for every discourse production, and they are themselves, simultaneously, a result of historical discourse formation. As Callon and others have shown for social studies of economics, and Bourdieu and his fellows have fully elaborated, fields are the manifestation and materialisation of language forms resulting from social struggles. Here, power is the possibility of discourses to produce 
Table 2.1 Performative, imaginary and symbolic power

\begin{tabular}{|c|c|c|c|}
\hline Type & Performative power & Imaginary power & Symbolic power \\
\hline Definition & $\begin{array}{l}\text { The possibility of } \\
\text { discourses to produce } \\
\text { sedimented categories } \\
\text { that are present in } \\
\text { the background to } \\
\text { future social action } \\
\text { on the imaginary and } \\
\text { symbolic levels }\end{array}$ & $\begin{array}{l}\text { The ability of every } \\
\text { discourse to create } \\
\text { images of the speaker, } \\
\text { the interlocutor and } \\
\text { many other social } \\
\text { roles }\end{array}$ & $\begin{array}{l}\text { The ability of discourses } \\
\text { to attribute respect, } \\
\text { prestige, authority, fear } \\
\text { and excitement to (an } \\
\text { image of) a person, an } \\
\text { institution or an object }\end{array}$ \\
\hline Example & $\begin{array}{l}\text { Institutional } \\
\text { infrastructures such } \\
\text { as contracts, money, } \\
\text { offices, organisations, } \\
\text { hierarchies }\end{array}$ & $\begin{array}{l}\text { Images such as "expert", } \\
\text { "racist", "Brexiteer", } \\
\text { "Londoner", } \\
\text { "neoclassic", } \\
\text { "Keynesian" }\end{array}$ & $\begin{array}{l}\text { Status positions such } \\
\text { as "scientific elite", } \\
\text { "Nobel Prize Award } \\
\text { winner", "excellence" }\end{array}$ \\
\hline
\end{tabular}

sedimented categories that are present in the background to future social action on the imaginary and symbolic levels.

Imaginary power is the ability of every discourse to create images of the speaker, the interlocutor and many other social roles. Actors never exist only for themselves. Rather, they always speak and act in the name of a certain image (the image of the mother and father in family discourse; the image of socialism, environmental sustainability, conservativism etc. in political discourse; and so forth). These images are important because they define how speakers present themselves and how they see others according to the knowledge attached to the images. Lacanian discourse theory calls this aspect of discourse the "imaginary level", because it defines the fundamental categories for the formation of subjectivities (Lacan, 1991). What we are to other people and how we see others depends on our active and passive position within this imaginary register. Whereas Foucault presented the idea of discursive subject positions, Lacan fully elaborated this dimension of discourse (Žižek, 1989). Power, in the imaginary register, is the possibility to define others and to be defined in a certain way.

Symbolic power is the ability of discourses to attribute respect, prestige, authority, fear and excitement to (an image of) a person, an institution or an object. In economic expert discourses, the prestige of certain institutions is often used to equip certain speakers with powerful discourse positions. Symbolic capital is an important category in Bourdieu's sociology because it introduces a form of hierarchisation in the field that is not based on typical forms of exclusion, such as economic, cultural and social capital. It is important because this form of power is always misrecognised by actors involved in the production of symbolic capital (Rossier \& Bühlmann, 2018). The "Nobel Prize Award" is a classic example (Lebaron, 2006). But the production and distribution of symbolic power cannot be detached from certain morphologies of social fields. In economic expert discourse, fields are always trans-epistemic and polycentric (Maesse, 2017b; Schmidt-Wellenburg, 2017b) because different fields and 
field logics interact and transgress each other. For this reason, prestige can be produced in one field and must be transmitted to another one, where it can be attached to certain imaginary speaker positions (Fitzgerald \& O'Rourke, 2015). Symbolic power is, therefore, the possibility of economic expert discourse to introduce hierarchies of perception in one field by importing "mythical capital" from another (Maesse, 2016).

\section{Three cases from the Brexit discourse}

This section will illustrate these three forms of discursive power with examples from the Brexit discourse. The empirical results are based on my sociological research on economic expert discourse. The data are collected by a multi-method research design consisting of capital analyses of academic fields (positions, publications, research grants based on economists' CV and homepage studies, analysis of data banks such as DFG and other sources), narrativebiographical interviews with economists, and discourse analyses of journal papers, policy papers, reports and media statements (see Maesse, 2015).

Brexit discourse is very much influenced by economic expert knowledge on very different levels. On the one hand, it is a discourse of critique of economic experts and the European Union (EU). On the other hand, "remainers" (people against the UK exiting the EU) as well as "leavers" (Brexit proponents) mobilise economic theory in order to support their position. Whereas remainers use a variety of new Keynesian, Keynesian, institutional and other economic arguments, the leavers align themselves with more or less classical and neoclassical free trade economics. Furthermore, even three years after the Brexit referendum in 2016, it is still not clear what it means to "leave" the EU. Thus, as this chapter will show, the UK is, with or without a deal, more or less part of the EU field that is highly influenced by economic expertise. This obscure situation is an interesting starting point for analysing what performative power means. This first subsection will illustrate the idea of performative power, taking the EU field and the British position in it as an example. The second subsection takes a conflict over economic policy to illustrate how imaginary power works. The third subsection will show how symbolic power is formed by examples from previous studies.

\subsection{Performative power: the economic formation of institutional relations and the place of the UK in the EU field}

Today, value chains, labour relations and economic services are no longer regulated by sovereign nation-states. They are rather organised on the basis of international agreements and rules. The European field is, for both internal and external relations, the most important playground for all the economic actors in Europe (EU, European Economic Area, European Free trade Association) (Jessop, 2012; Sweet, Sandholtz, \& Fligstein, 2001). The European Union as an institutional field has been formed in a long historical process by translating 
economic language into governmentality apparatuses (Schmidt-Wellenburg, 2017a). As Mudge and Vauchez (2012) have demonstrated, language from the field of economics (and law) is used to make Europe calculable and manageable, even if (or because of) the original academic meaning of economic concepts changes in contexts of governance, finance, business and trade.

Against this backdrop, words from the economics discipline have always had a metaphorical character (Maesse, 2017a), otherwise they would not be transferable in non-academic contexts. In the course of the formation of the EU, starting with the Treaty of Rome in 1957 and leading to the never-ending reform of EU treaties, the so-called Four Freedoms have been established: the customs union, the common market, the capital union and the free movement of persons. But these Four Freedoms are not simply neoliberal concepts set in stone and functioning as authoritarian dogmas (Bruff, 2014). Most European policies are neoliberal, but the institutions and contracts as such are not. Rather, they regularly become an object of reform, interpretation and adoption to the diverse problems in the history of Europe (Miró, 2017). Performative power does not mean that content (as meaning) from economics is implemented in social reality. Rather, economic language, as discourse, can be used and applied in diverse contexts only if meaning changes. Therefore, the Four Freedoms have no singular content. On the contrary, their content was always subject to conflicting interpretations (see Nicoletta in this volume).

The studies by Seikel and Costantini demonstrate this interpretative flexibility and discursivity of economic language in the course of the ongoing institutionalisation of Europe as a field (Costantini, 2017; Seikel, 2016). Costantini shows how the most important institutional framework of the EU, the Stability and Growth Pact, was constantly changed after 1992. Furthermore, it was not only the legal framework that was reformed. The ways to implement this framework in different countries and in different historical and economic circumstances, by calculating national budgets through macro-economic valuations, have also constantly changed. For example, to qualify a certain measure, such as expenses for infrastructure or a tool for "increasing competitiveness", or to disqualify it as "budgetary expenses" results from expert interpretations by the EU administration. The meaning of a contract is not manifested in the paragraphs. Meaning results from the way these contracts are interpreted and applied. In line with this view, Seikel shows how austerity measures during the crisis were implemented completely differently in different crisis-ridden countries. Similar phenomena can be observed in the crisis policy of the European Central Bank. The statutes of the ECB do not determine social action. As an institution they rather provide actors (members of the board, staff members, other experts) with discursive material open to interpretation.

What we learn from these examples is that institutions, in light of performative power, are not closed entities, neither legally fixed contracts nor socially habitualised routines. They are rather material background and raw material for further discourses. This property becomes particularly important in the Brexit discourse. The UK became a member of the EEC/EU in 1973. Even if the UK 
did not adopt the euro currency and did not sign the Schengen Agreement, almost all the activities on the state and economic levels take place within the European field. The UK is furthermore as deeply integrated as the average EU country into this field: $50 \%$ of all exports from and imports to the UK take place within the EU; the UK has a trade-balance deficit and does therefore depend on industrial production and services in other EU member states; and the economic heart of the UK, the City of London, depends on trading partners in the EU. The financial sector in the City of London is not an average sector of the national economy. It is rather a highly specialised sector that only can exist as part of the EU-wide division of labour. And even if the UK is not part of the Schengen Area, it nevertheless recruits approximately three million workers from other EU countries, appointed at all levels of income and qualifications. In exchange for that, British pensioners spend their sunset years in Spain. It is an illusion to believe that the UK stands outside the EU; it is rather part of the EU field produced by performative power.

However, what does "Brexit" mean against the backdrop of this deep involvement of the UK in the EU? Brexit means that old discursive-economic categories will be suspended and detached from diverse persons and economic activities. Capital transfers from the UK to the EU will no longer be easy; lorries will not easily cross the border to EU; aeroplanes may not take off and land. In order to avoid disruption, chaos and civil-war-like scenarios, a new contract must ensure that future social action is possible (within the UK and between UK and the rest of the world). An agreement between the EU and the UK was negotiated in 2018 for that reason: "the deal". In order to illustrate what I mean by the performative power of economics, I will briefly show how economics language can be used to create new institutional terrains. The following paragraph is part of the "deal" between the UK and the EU, ratified by EU institutions and member states and the UK.

Article 24 of the Brexit agreement regulates the rights and duties of people who fall under the category of "workers".

Subject to the limitations set out in Article 45(3) and (4) TFEU, workers in the host State and frontier workers in the State or States of work shall enjoy the rights guaranteed by Article 45 TFEU and the rights granted by Regulation (EU) No 492/2011 of the European Parliament and of the Council. These rights include:

(a) the right not to be discriminated against on grounds of nationality as regards employment, remuneration and other conditions of work and employment;

(b) the right to take up and pursue an activity in accordance with the rules applicable to the nationals of the host State or the State of work;

(c) the right to assistance afforded by the employment offices of the host State or the State of work as offered to own nationals; 
(d) the right to equal treatment in respect of conditions of employment and work, in particular as regards remuneration, dismissal and in case of unemployment, reinstatement or re-employment;

(e) the right to social and tax advantages;

(f) collective rights;

(g) the rights and benefits accorded to national workers in matters of housing;

(h) the right for their children to be admitted to the general educational, apprenticeship and vocational training courses under the same conditions as the nationals of the host State or the State of work, if such children are residing in the territory where the worker works.

Some people may doubt the underlying hypothesis that the category "worker" is a category from economic science. But, as studies on the history of scientific knowledge have shown, diverse labour-related categories such as "worker" became part of the economics discourse, especially in the 19th and 20th centuries, and from there they entered the political and administrative discourses of the emerging nation-state order (Desrosières, 1998; Wagner, 2001). Therefore, we follow those studies that presuppose that all categories related to the formation of the Four Freedoms, such as "worker", are somehow related to economics as a special realm of knowledge and language production. In the case of the worker category, this seems to be quite obvious, since alternatives for categorising persons come quickly to hand: "citizen", "human being", "person" etc. And all of them would probably impact on performative possibilities in a certain direction.

What makes an economic category such as "worker" performative is the fact that this category is not only used for a pure designation and description of people or other entities. It is also a category to be used as a legal entity. Special legal organisations are allowed and obliged to confer particular rights and duties on persons according to well-defined criteria. On the other hand, people can claim certain rights and duties when they rely on the category of "worker". For example, when a European citizen has a contract with a British organisation that is allowed to act as an employer, s/he can claim to be a "worker" and is now allowed to live in the UK, to bring his/her family to the UK, to use the British health system (NHS) and so forth. Generally speaking, the performative power of economic categories is only occasionally related to the original conceptual meaning of a word (in economic science). Rather, performative power implies that people can speak and act in the name of this category and start to produce further discourses, actions and artefacts.

Performative power provides human beings with a special status. In the production of this status, many people, institutions and organisations are involved because institutionalisation in the course of performative power formation is an ongoing process of permanent formulation, transformation and reformulation of that status. For example, what a "worker" is or can be is not only defined 
by European acts, contracts and agreements. When such agreements are made, many other institutions start to interpret the diverse paragraphs and apply them to many different cases. In these processes of what I would call secondary institutionalisation/performations, European institutions will be changed and reformed, as we have seen in the aforementioned cases of the Stability and Growth Pact, austerity programmes and ECB policy. In the course of these permanent performations and transmutations, a European field constellation emerges as a contested and never fixed background for further discursive actions in all realms of European societies. The EU field cannot be reduced to the "Eurocracy" (Georgakakis \& Rowell, 2013) in Brussels; rather it reaches across many levels of all European societies (Delanty \& Rumford, 2005). Therefore, the performative power of economics means that social realities are produced by metaphorical uses of economic language.

Particularly interesting is what happens when certain performative categories are detached from people. This necessarily leads to the dissolution of diverse field belongings and can open up social fields to chaos and anarchy. The alternative to being a member of the EU (exiting the EU) is therefore not another positive state or another field belonging. It is probably furthermore a state of "pure negativity", the negation of institutional existence. This threat is at work during the ongoing Brexit discourse where an exit agreement is negotiated but a final deal not yet reached by EU and UK officials. This limbo leads to insecurity, anxiety, discursive chaos, hysteria and all the other psychotic states that can be observed in the UK since 2016. The next subsection will take this situation of psychotic field limbo that rules the UK discourse to look at the imaginary level of discourse production.

\subsection{Imaginary power: the discursive formation of expert positions as political identities}

To illustrate imaginary power, an example from economic expert discourses on the possible economic effects of Brexit on the UK economy will be selected. The following excerpt is taken from a response by one group of economists to another group called "Economists for Brexit". Patrick Minford, professor at Cardiff University and one of the "Economists for Brexit", predicts a welfare gain from Brexit of 4\% GDP growth, provided by a "British Alone" strategy that would mean removing all barriers to world trade. The authors of the response, from which the following excerpt is taken, are appointed by the Centre for Economic Performance (a research centre at the London School of Economics) and reject Minford's expertise as follows:

Minford's results stem from assuming that small changes in trade costs have tremendously large effects on trade volumes: according to his model, the falls in tariffs become enormously magnified because each country purchases only from the lowest cost supplier. 
In reality, everyone does not simply buy from the cheapest supplier

Products are different when made by different countries and trade is affected by the distance between countries, their size, history and wealth (the 'gravity relationship'). Trade costs are not just government-created trade barriers. Product differentiation and gravity is incorporated into modern trade models - these predict that after Brexit the UK will continue to trade more with the EU than other countries as it remains our geographically closest neighbour. Consequently, we will be worse off because we will face higher trade costs with the EU.

(Economists for Brexit: A Critique by Sampson et al., 2016)

In the following discourse analysis of the excerpt I want to show how enunciative markers form speaker positions which are a discursive precondition for social role and identity formation (Angermuller, 2014; Fløttum, 2005; Zienkowski, 2016). Enunciative markers evoke linguistic speaker roles that can be adopted by diverse social actors in order to create identity images. The image of "me" and the images of "others" are important parts of an actor's identity/ image. They are created as discursive roles. The idea of this approach is that such discursive roles always operate with diverse images of the speaker and the other (Goffman, 1974). Based on Lacan's and Foucault's discourse theory (Foucault, 1972; Lacan, 1991), the following analysis shows how such images are formed by the textual use of deixis, negation, booster and hedges in the aforementioned discourse.

For illustrative reasons, I only take one sentence (in italics) which is of central importance in this process of identity and image formation. Whereas the first part presents Minford's thesis very quickly, the authors use this sentence to bridge the argumentation from Minford's argument to their own standpoint. The linguistic modalities that are at work in this sentence have nothing to do with the conceptual content of either expert statement (Minford's and their own). Rather, it works as a discursive-cognitive tool that directs the consciousness of any potential reader to certain images of opponent (Minford) and proponent (authors). Those discursive markers produce a certain ethos, as Maingueneau would put it (Maingueneau, 1999), and they introduce the dimension of political struggle into expert discourses (Maesse, 2017a; Pühringer \& Hirte, 2015). Therefore, economic expert discourses are not simply representing ideas, concepts and arguments; they are also a tool in social conflicts over hegemony (O’Rourke \& Hogan, 2014).

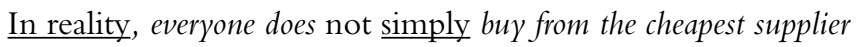

In a first step, let's take a look at the formal level of this short utterance. The speaker's position is basically produced by antagonism to Minford's economic view. This antagonism is evoked by an operator of negation ("not"), 
a presupposition booster ("in reality") and a hedger ("simply"). What does it mean for the production of certain images? In a first move, the authors create their own image by opposing Minford's position. In order to reject that image, an image of "Minford" (the other) must be produced first. Two discursive perspectives (points of view: pov) represent this image of the other (where (a) refers to the "other" of the discourse and (l) to the position of the speaker):

$\operatorname{pov}_{1}(\mathrm{a})$ : "small changes in trade costs have tremendously large effects on trade volumes (since) the falls in tariffs become enormously magnified because each country purchases only from the lowest cost supplier" (presupposed here, taken from the aforementioned statement [in italics])

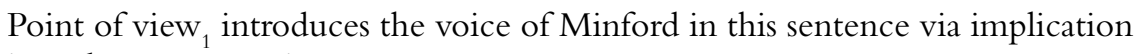
in order to oppose it:

$\operatorname{pov}_{2}(1):$ NO $\operatorname{pov}_{1}$, BECAUSE $=$ "not real" (presupposition: true statements must be "real", evoked by "in reality")

Therefore, the formulation "in reality" evokes a two-step cognitive process: in a first step, the initial statement is reintroduced; and in a second step, the speaker goes on to distance themselves from it. But this second step is only made possible by making a positive reference to something that is "real". This comes in the statement: "everyone does not simply buy from the cheapest supplier". Thus, the solidarity with speaker 2 is represented by the (l) in pov $_{2}$, whereas opposition to the image of the opponent is indicated by the (a) in pov $_{1}$. Now, the discourse reaches its final moment because the image of the "me" position is developing:

$$
\operatorname{pov}_{3}(a) \text { : "everyone does buy from the cheapest supplier" }
$$

But before the speaker comes to their argument ("Products are different when made by different countries and trade is affected by the distance between countries, their size, history and wealth (the 'gravity relationship')") the opponent is again evoked by the discourse through negation ("not"):

$$
\operatorname{pov}_{4}(1): \mathrm{NO} \text { pov }_{3}
$$

This is even highlighted by a booster ("simply"):

$$
\begin{aligned}
& \operatorname{pov}_{5}(1): \operatorname{pov}_{4} \text { IS OBVIOUSLY CORRECT BECAUSE pov }{ }_{3} \text { IS SO } \\
& \text { RIDICULOUS (implicit comment on pov } \\
& \text {, evoked by "simply") }
\end{aligned}
$$

What we can learn from this discourse is that the "me" image (all pov with (1)) cannot be produced without permanently repeating and reintroducing the 
image of the "other" (Minford, all pov with (a)). Furthermore, both discursive images are obviously the result of a certain polemical rhetoric. The other is not only presented twice $\left(\operatorname{pov}_{1,3}\right)$ but is three times rejected $\left(\operatorname{pov}_{2,4,5}\right)$. Strictly speaking, it can be said that the other has five images: two positive images and three rejections of them.

Depending on the emotional contexts in which those statements are read and used for further discourses, polemical modalities create huge gaps between political and professional counterparties. In this example, it is easily imaginable how "rational people" with "obvious and simple economic arguments" enter into strict opposition to a group of economists who have "lost contact with reality". On the other hand, in a situation where the institutional infrastructure of the UK reality becomes more and more precarious, people such as Minford can easily present "old-fashioned" economic arguments that are, in the eyes of many other experts, far away from the data and the current economic discussion. The moment of institutional disintegration might be when "zombies" (Zizek) enter the scene, because the Lacanian "real" suspends the "symbolic reality" (guaranteed by the institutional order).

However one reads this situation, depending on the standpoint and possible contexts of controversy, economic expert discourses can produce strong images of social actors. And these images can have a huge influence on how certain economic arguments are presented and perceived. This is basically the idea of imaginary power. Imaginary power cannot make certain things true or false. It is, rather, a way of producing images of real actors, and the potential reputation of these real social actors highly depends on the image that we have in mind when we listen to a speech, argumentation or an economic expert proposal. Discursive markers such as deixis, negation, boosters and hedges (and many more) can contribute to creating those identity images.

\subsection{Symbolic power: how economic experts get reputation and legitimacy}

In processes of formation and attribution of reputation, the image is only one aspect, even if this aspect is fundamentally important to construct social individuals as professional actors. In addition, symbolic power can support (or hinder) the formation of power connected to certain actors in discourses. Whereas the linguistic dimension forms images as power devices, symbolic power is not solely produced by ordinary speech acts. It rather presupposes the existence and operation of an institutionalised field that is not immediately involved in these politico-economic struggles. According to the sociology of professions, experts are always recognised by non-experts. For this reason, symbolic power must be produced in a place where it is not used, and it must be used in a place where it is not directly produced. The fields of production the "factories of symbolic goods" as places of value creation) are not the fields of consumption ("the markets" as sites of price realisation). The structural condition for the possibility of legitimacy of expertise as such is based on the 
existence of a constellation of different sub-fields between academia and society (Hirschfeld \& Gengnagel, 2017). The formation of reputation is finally the product of various discourses taking place at the interface of these sub-fields between academia and society.

Therefore, the world of economic experts is embedded in a trans-epistemic field that reaches across academia, politics, media and the economy (Maesse, 2015), and it produces diverse sources of legitimacy (Schmidt-Wellenburg, $2017 b)$. Symbolic power is the product of discursive interplay between the academic field, the political field, the economic field and public discourses in the media. The possibility to confer respect, prestige and legitimacy on an economic expert in public political discourse is based on the production of "excellence" and "elite" labels as "mythical capital" in academia (Maesse, 2017b). According to this model, almost all economists who are involved in societal discourses on economic policy - such as the Minford debate presented earlier - can profit from "discourses of excellence" produced within academic daily life. Academia is like a "political production facility" for manufacturing symbolic capital to be used in political and media discourses.

In economics, discourses of excellence emerge within strong academic hierarchies that are formed by diverse concentric networks. The most important mechanism at work in these hierarchisations and elitisations is the mutual interaction of research rankings, excellence-oriented funding from the Research Excellence Framework (REF), the de facto dominance of only a few economics departments in the UK (such as the London School of Economics (LSE), Oxford, University College London, Warwick and a few others) and the role of exclusive clubs and networks such as the Centre for Economic Policy Research (CEPR) and other informal settings (Lee, Pham, \& Gu, 2013; Maesse, 2018b). The detailed interplay of these technologies cannot be analysed here, but what can be said is that those elite networks do not simply produce academic elite positions. What they actually form is the idea of excellence, i.e. the material exemplification of the possibility that academic exceptionalism - as "excellence" - can exist.

Many economists from these elite networks obtain powerful positions within academia, and many of them move on to work in banks, international organisations, governments and central banks. Symbolic power is not attached to a single position in these kinds of networks. It is rather a structural effect of the entire network, and in discourses it can be easily attached to any sort of economic statement. For example, Patrick Minford is an economics professor at Cardiff University and simultaneously a Fellow of the CEPR network. The authors of the "response" to Minford's Brexit position are appointed by the LSE, which has a highly prestigious economics department. Therefore, both opponents and proponents of the previously analysed discourse may benefit from the institutional reputation of the very same elite structure. Symbolic power is therefore not connected to "true concepts" or "functioning ideas". Rather, it privileges, authorises and legitimises economic experts' speaker positions in discourses. 


\section{Conclusion}

To conclude, all the different sorts of discursive power presented here interact with each other. Each form of power always presupposes all the other forms. There is no constitutive hierarchy between them. Rather, they are linked to each other like Lacan's rings. One sort builds on another, forming a network of power and knowledge that stretches across various fields in academia, politics, the economy and media. As this chapter argues, performative, imaginary and symbolic forms of power are key elements to understand the impact of economic expert knowledge on society. As discursive forms of power, these three forms can deal with certain problems in social studies of economics: first, we can understand how certain linguistic forms meld with socio-material relations on different levels resulting in structural constraints; second, we can grasp the translational character of economic experts' impact occurring between distinct social fields and mediated by discourses; third, we can analyse power on various levels and take into account the complexity of economic expert discourses.

This discourse analytical perspective on power opens up our analytical focus for the heterogeneity of the social that is evolving in the course of globalisation. With such an approach to hand, we are not obliged to assume a mysterious "global structure of meaning", as world polity approaches do (Meyer, Boli, Thomas, \& Ramirez, 1997), and neither are we expected to reduce everything to the micro level of social interaction due to a lack of structuring terrains (Knorr Cetina \& Bruegger, 2002). On the contrary, we can now grasp and analyse the diverse forms of social struggle taking place at various levels of globalised societies in-between the local and the global.

\section{References}

Angermuller, J. (2014). Poststructuralist discourse analysis: Subjectivity in enunciative pragmatics. London: Palgrave.

Boldyrev, I., \& Svetlova, E. (Eds.). (2016). Enacting dismal science: New perspectives on the performativity of economics. London and New York: Palgrave Macmillan.

Bourdieu, P. (1989). Distinction: A social critique of the judgement of taste. London: Routledge. Bruff, I. (2014). The rise of authoritarian neoliberalism. Rethinking Marxism, 26(1), 113-129.

Callon, M. (2007). What does it mean to say that economics is performative? In D. MacKenzie et al. (Eds.), Do economists make markets? On the performativity of economics (pp. 311357). Princeton: Princeton University Press.

Costantini, O. (2017). Political economy of the Stability and Growth Pact. European Journal of Economics and Economic Policies: Intervention (14), 333-350.

Delanty, G., \& Rumford, C. (2005). Rethinking Europe: Social theory and the implications of Europeanization. London and New York: Routledge.

Desrosières, A. (1998). The politics of large numbers: A history of statistical reasoning. Cambridge and London: Oxford University Press.

Dezalay, Y., \& Garth, B. (2009). National usages for a "global" science: The dissemination of new economic paradigms as a strategy for the reproduction of governing elites. In G. Mallard, C. Paradeise, \& A. Peerbaye (Eds.), Global science and national sovereignty. Studies in historical sociology of science. New York: Routledge. 


\section{Jens Maesse}

Fitzgerald, J., \& O'Rourke, B. K. (2015). Performing economics: How economics discourse gets enacted in radio news interviews. Presented at the 10th international conference in interpretive policy analysis.

Fløttum, K. (2005). The self and the others: Polyphonic visibility in research articles. International Journal of Applied Linguistics, 15(1), 29-44.

Foucault, M. (1972). The archaeology of knowledge. New York: Pantheon Book.

Foucault, M. (1980). Power/knowledge: Selected interviews and other writings, 1972-1977. New York: Pantheon.

Foucault, M. (2008). The birth of biopolitics. Lectures at the Collège de France, 1978-1979. New York: Palgrave Macmillan.

Georgakakis, D., \& Rowell, J. (2013). The field of Eurocracy: Mapping EU actors and professionals. London: Palgrave.

Goffman, E. (1974). Frame analysis: An essay on the organization of experience. Cambridge: Harvard University Press.

Hall, P. A. (Ed.). (1989). The political power of economic ideas: Keynesianism across nations. Princeton: Princeton University Press.

Hamann, J., Maesse, J., Scholz, R., \& Angermuller, J. (2019). The academic dispositif: Towards a context-centred discourse analysis. In R. Scholz (Ed.), Quantifying approaches to discourse for social scientists (pp. 51-87). London and New York: Palgrave Macmillan.

Hirschfeld, A., \& Gengnagel, V. (2017). 'Das können wir nicht durchgehen lassen': Zur gesellschaftlichen Resonanz kritischer Interventionen. In J. Hamann, J. Maesse, V. Gengnagel, \& A. Hirschfeld (Eds.), Macht in Wissenschaft und Gesellscht: Diskurs- und feldanalytische Perspektiven (pp. 425-452). Wiesbaden: Springer.

Hirschman, D., \& Popp Berman, E. (2014). Do economists make policies? On the political effects of economics. Socio-Economic Review, 12, 779-811.

Jessop, B. (2012). The world market, variegated capitalism, and the crisis of European integration. In P. Nousios, H. Overbeek, \& A. Tsolakis (Eds.), Globalisation and European integration: Critical approaches to regional order and international relations (pp. 91-111). London and New York: Routledge.

Knorr Cetina, K., \& Bruegger, U. (2002). Global microstructures: The virtual societies of financial markets. American Journal of Sociology, 107(4), 905-950.

Lacan, J. (1991). Das Seminar Buch 2, Das Ich in der Theorie Freuds und in der Technik der Psychoanalyse. Weinheim: Quadriga.

Lebaron, F. (2006). 'Nobel' economists as public intellectuals: the circulation of symbolic capital. International Journal of Contemporary Sociology, 43(1), 88-101.

Lebaron, F. (2008). Central bankers in the contemporary global field of power: A 'social space' approach. The Sociological Review, 56(1), 121-144.

Lee, F. S., Pham, X., \& Gu, G. (2013). The UK research assessment exercise and the narrowing of UK economics. Cambridge Journal of Economics, 37(4), 693-717.

MacKenzie, D., \& Millo, Y. (2003). Constructing a market, performing theory: The historical sociology of a financial derivatives exchange. American Journal of Sociology, 109, $107-145$.

Maesse, J. (2015). Economic experts: A discursive political economy of economics. Journal of Multicultural Discourses, 10(3), 279-305.

Maesse, J. (2016). The power of myth. The dialectics between 'elitism' and 'academism' in economic expert discourse. European Journal of Cross-Cultural Competence and Management, $4(1), 3-20$.

Maesse, J. (2017a). Austerity discourses in Europe: How economic experts create identity projects. Innovation: The European Journal of Social Science Research, 1-17. 
Maesse, J. (2017b). The elitism dispositif: Hierarchization, discourses of excellence and organizational change in European economics. Higher Education, 73(6), 909-927.

Maesse, J. (2018a). Discursive Marxism: How Marx treats the economy and what discourse studies contribute to it. Critical Discourse Studies, 4(15), 364-376.

Maesse, J. (2018b). Globalization strategies and the economics dispositif: Insights from Germany and the UK. Historical Social Research, 43(3), 120-146.

Maingueneau, D. (1999). Analysing self-constituting discourses. Discourse Studies, 1(2), 183-199.

Meyer, J. W., Boli, J., Thomas, G. M., \& Ramirez, F. O. (1997). World society and the nation-state. American Journal of Sociology, 103(1), 144-181.

Miró, J. (2017). European integration, social democratic Europeanism and the competitiveness discourse: A neo-Poulantzian approach to discursive policy analysis. Palgrave Communications (4). DOI: 10.1057/palcomms.2017.60.

Mirowski, P., \& Nik-Khah, E. (2008). Command performance: Exploring what STS thinks it takes to build a market. In T. Pinch \& R. Swedberg (Eds.), Living in a material world: Economic sociology meets science and technology studies (pp. 89-128). Cambridge: MIT Press.

Mudge, S. L., \& Vauchez, A. (2012). Building Europe on a weak field: Law, economics, and scholarly avatars in transnational politics. American Journal of Sociology, 118(2), 449-492.

O'Rourke, B. K., \& Hogan, J. (2014). Guaranteeing failure: Neoliberal discourse in the Irish economic crisis. Journal of Political Ideologies, 19(1), 41-59.

Pühringer, S., \& Hirte, K. (2015). The financial crisis as a heart attack: Discourse profiles of economists in the financial crisis. Journal of Language and Politics, 14(4), 599-625.

Rossier, T., \& Bühlmann, F. (2018). The internationalisation of economics and business studies: Import of excellence, cosmopolitan capital, or American dominance? Historical Social Research, 43(3), 189-215.

Rossier, T., Bühlmann, F., \& Mach, A. (2017). The rise of professors of economics and business studies in Switzerland: Between scientific reputation and political power. European Journal of Sociology/Archives Européennes de Sociologie, 58(2), 295-326.

Sampson, T., Dhingra, S., Ottaviano, G., \& Van Reenen, J. (2016). Economists for Brexit: A Critique. CEP Brexit Analysis No. 6, Page 1. http://cep.lse.ac.uk/pubs/download/ brexit06.pdf.

Schmidt-Wellenburg, C. (2017a). Europeanisation, stateness, and professions: What role do economic expertise and economic experts play in European political integration? European Journal of Cultural and Political Sociology, 1-27.

Schmidt-Wellenburg, C. (2017b). Wissenschaft, Politik und Profession als Quellen diskursiver Autorität. In Macht in Wissenschaft und Gesellschaft (pp. 477-504). Wiesbaden: Springer.

Seikel, D. (2016). Flexible austerity and supranational autonomy. The reformed excessive deficit procedure and the asymmetry between liberalization and social regulation in the EU. Journal of Common Market Studies, 54(6), 1398-1416.

Sweet, A. S., Sandholtz, W., \& Fligstein, N. (Eds.). (2001). The institutionalization of Europe. Oxford: Oxford University Press.

Wagner, P. (2001). A history and theory of the social sciences: Not all that is solid melts into air. London and New York: Sage.

Weber, M. (1972). Wirtschaft und Gesellschaft: Grundriss der verstehenden Soziologie. Tübingen: Mohr Siebeck.

Zienkowski, J. (2016). Articulations of self and politics in activist discourse: A discourse analysis of critical subjectivities in minority debates. London: Palgrave.

Žižek, S. (1989). The sublime object of ideology. London and New York: Verso. 